\title{
LA ARMADA Y LA IGLESIA EN TIEMPOS DE INDEPENDENCIA: LA ASOCIACIÓN DE JESÚS SACRAMENTADO DE CARTAGENA, 1808-1814*
}

\author{
POR \\ JUAN JOSÉ SÁNCHEZ BAENA ${ }^{1}$ \\ Universidad de Murcia \\ Y \\ ANTONIO IRIGOYEN LÓPEZ ${ }^{2}$ \\ Universidad de Murcia
}

\begin{abstract}
RESUMEN
El presente trabajo pretende analizar la introducción de la Armada en la esfera religiosa de la ciudad de Cartagena gracias a su alianza con la Iglesia católica. Debido a la situación de inestabilidad generada por la Guerra de la Independencia, los oficiales de la Marina quedaron encargados de la defensa de la ciudad y fueron mayoría dentro de la Junta local, lo que significó que habría de ocuparse también de asuntos religiosos. En este contexto se funda la Asociación de Jesús Sacramentado, cuyos cargos directivos serán ocupados preferentemente por oficiales de la Armada, la cual se reservaba, de este modo, un espacio propio dentro del panorama religioso de la ciudad.
\end{abstract}

PALABRAS CLAVE: Armada; Iglesia católica; religión; oligarquía; Guerra de la Independencia; Cartagena; Siglo XIX.

\section{THE NAVY AND THE CATHOLIC CHURCH IN TIMES OF INDEPENDENCE: THE ASSOCIATION OF THE BLESSED SACRAMENT OF CARTAGENA, 1808-1814}

\begin{abstract}
This paper analyzes the introduction of the Navy in the religious sphere of the city of Cartagena through its alliance with the Catholic Church. Due to the instability generated by the War of Independence, Navy officers were responsible for the defense of the city. They dominated the local Board, which also deal with religious issues. In this context, the Association of the Blessed Sacrament is based. Navy officers occupied leadership positions. In this way the Navy got to have their own space within the religious landscape of the city.
\end{abstract}

KEY WORDS: Navy; Catholic Church; Religion; Oligarchy; War of Independence; Cartagena; Nineteenth Century.

Cómo CITAR ESTE ARTículo / CitATION: Sánchez Baena, J. J. e Irigoyen López, A. 2017. "La Armada y la Iglesia en tiempos de Independencia: la Asociación de Jesús Sacramentado de Cartagena, 1808-1814». Hispania Sacra 69, 139: 319-332. doi: 10.3989/ hs.2017.022

$\begin{array}{ll}\text { Recibido/Received } & 24-02-2015 \\ \text { Aceptado/Accepted } & 22-04-2016\end{array}$

De entrada, una obviedad. Una guerra altera la vida cotidiana de una sociedad, de una localidad, de una comunidad, de los individuos. Algunas cosas se mantienen, otras se

\footnotetext{
*Este trabajo se inscribe en el Proyecto I+D+I Nauticum 19496/ $\mathrm{PI} / 2014$, patrocinado por la Fundación Séneca-Agencia Regional de Ciencia y Tecnología de la Región de Murcia, y en el Proyecto de Investigación HAR2013-48901-C6-1-R: Familias e Individuos: Patrones de Modernidad y Cambio Social (siglos XVI-XXI), financiado por el Ministerio de Economía y Competitividad del Gobierno de España.

1 baena@um.es/ORCIDiD: http://orcid.org/0000-0002-5965-9016

2 adiri@um.es / ORCID iD: http://orcid.org/0000-0002-0103-0135
}

renuevan y otras, en fin, surgen. Esta inestabilidad explica los cambios que pueden aparecer y que no siempre -aunque, a veces, sí- son consecuencia directa del conflicto bélico. Uno de los paradigmas que quizás sintetiza todo lo anterior son las Cortes de Cádiz y la Constitución de 1812, surgida en plena Guerra de la Independencia. Se aprovechó la inestabilidad para alumbrar un nuevo ordenamiento, en el cual la Nación se convierte en el principal sujeto político, en el depositario de la soberanía. Tener en cuenta las circunstancias bélicas en que surgió la Constitución, sin duda ayuda a comprender algunas de las decisiones adoptadas en ese momento histórico. 
Ríos de tinta se han vertido en los últimos años acerca de la Guerra de la Independencia, las Cortes de Cádiz y la Constitución de 1812, aprovechando la celebración de los correspondientes aniversarios. La cuestión religiosa y sus consecuencias políticas en la España contemporánea, al amparo de la tensión entre clericalismo y anticlericalismo, ${ }^{3}$ quizás haya sido uno de los temas que más atención ha recibido y que, por fortuna, ha dado lugar a estudios y trabajos de gran calidad que han permitido avanzar en el conocimiento historiográfico. ${ }^{4}$ En estas obras, como no podía ser menos, el eje central es el peso que pudo tener el catolicismo en la toma de decisiones políticas. El concepto de ciudadanía católica propuesto por Gregorio Alonso o el estudio conjunto de clericalismo y anticlericalismo, profundizando una línea abierta hace algunos años por autores como Julio de la Cueva, se han revelado últimamente como vías analíticas muy fructíferas. ${ }^{5}$

Sin embargo, en la mayoría de los trabajos se echa en falta el estudio de lo local, puesto que se han centrado en el análisis de la alta política a escala nacional. Hay poca información sobre cómo fue el panorama religioso en los pueblos y ciudades en los años de la Guerra de la Independencia. ${ }^{6}$ Es cierto que se han tratado bastante los sermones como una herramienta fundamental para conocer la situación religiosa, así como el contenido religioso que se dio a la contienda, con el fin de propiciar la movilización y el alistamiento. ${ }^{7}$ Estos trabajos están obteniendo resultados notables, como el estudio de los sitios de Zaragoza y Gerona, que establece que el elemento religioso en las actuaciones y discursos no es que estuviera presente, es que resultó fundamental. ${ }^{8}$ Es interesante, por tanto, profundizar en esta problemática. ¿Cómo fue a escala local la relación entre política e Iglesia? ¿Cómo se configuró el poder? ¿Qué papel se asignó a la religión y a los eclesiásticos en este proceso?

Estas y otras cuestiones son las que se plantean en el presente trabajo. Para lograrlo se va a proceder al examen de una ciudad concreta, Cartagena, en esos años, con el fin de poder determinar las consecuencias que pudieron tener en la realidad local del siglo xIx. La hipótesis de partida que plantea es que, en un contexto bélico de gran inestabilidad, en la ciudad de Cartagena la religión será un instrumento utilizado para configurar el poder político y asentar a las oligarquías, dentro de las cuales la presencia de oficiales de la Armada desempeñará un papel nada desdeñable. Durante la Guerra de la Independencia se va a producir una simbiosis entre la Iglesia y la Armada, y este hecho tendrá consecuencias indudables para la evolución del panorama religioso en la Cartagena contemporánea. Marino será el Capitán General, que era la máxima autoridad política y militar de la ciudad. Marinos habrá en la Junta de Observación y Defensa, y a ellos se les encomendará el mantenimiento de las murallas y defensas. ${ }^{9}$ Marinos, por fin, habrá en el ámbito de la

\footnotetext{
3 Alonso 2014.

4 Por citar tan sólo unos ejemplos recientes dentro de un notable conjunto que se pueden añadir a la obra ya citada de Gregorio Alonso: Suárez Cortina 2014; Barrio Gozalo 2012 y Robles 2010

5 De la Cueva Merino 1994.

6 Un buen trabajo sobre el balance historiográfico se puede encontrar en Andrés-Gallego 2009.

7 Barbastro Gil 1987.

8 Barnosell Jordá 2010

9 Roda Alcantud 2008.
}

religión en una iniciativa que surge en estos momentos: la Asociación de Jesús Sacramentado.

Para llevar a cabo este propósito se han contado con unas fuentes excepcionales. En primer lugar, el Libro de la Asociación de Jesús Sacramentado que, procedente del Fondo Cañabate, se conserva en la actualidad en el Archivo Municipal de Cartagena. ${ }^{10}$ Lo valioso de este documento es que el religioso franciscano descalzo que fue el principal promotor del proyecto, el hermano Jerónimo Navarro, cuenta en primera persona cómo fue el proceso que terminó con la fundación de la asociación, ofreciendo un retrato fresquísimo de los notables de la ciudad; igualmente en dicho libro se incluyen diferentes documentos, así como acuerdos de las reuniones. Estas informaciones se han completado también con otras fuentes que contienen noticias de la ciudad de Cartagena en esta época.

\section{CARTAGENA A FINALES DEL SIGLO XVIII Y PRINCIPIOS} DEL SIGLO XIX

La ciudad de Cartagena experimentó un notable desarrollo durante el siglo XVIII, a raíz del establecimiento del Departamento marítimo y de la construcción del Arsenal, que era un centro industrial innovador. ${ }^{11}$ Asimismo la Academia de Guardiamarinas, establecida en 1777, atrajo a nutrido número de aspirantes de toda la Monarquía, y en su calidad de centro de formación elitista se convirtió en un difusor de la ciencia ilustrada. ${ }^{12}$ Todo lo cual contribuyó a incrementar la tendencia de crecimiento demográfico que se produjo en el conjunto del Reino de Murcia. Así, Cartagena, según el censo de Floridablanca de 1787, contaba con una población de 45.217: 28.679 habitantes en la ciudad y 16.538 , en el campo.

Además, Cartagena se presentaba como un centro marítimo militar y comercial de primer orden, no sólo a nivel nacional, sino en todo el ámbito mediterráneo, tal y como Fray Leandro Soler describía en el año 1777, ofreciendo un notable testimonio del desarrollo urbano:

Hoy es una ciudad de las mas famosas de Europa (...) brilla engrandecida con sus hermosas y anchas calles y plazas, por sus muchos balconages de hierro con que se adornan sus elegantes casas y otros edificios (...) por lo que mira al recinto de la Ciudad y barrios contiguos, se miran en el día tan ocupados de casas que no hay palmo de sitio que no esté fabricado; y por no ser todavia habitación suficiente para el innumerable gentio que se le ha avecindado; se halla extendida a tres barrios separados que son el de San Antón, Santa Lucia y el de Quitapellejos. ${ }^{13}$

Sin embargo, esta etapa de expansión se frena hacia finales del siglo XVIII, de tal modo que las primeras décadas del siglo XIX son para Cartagena una época especialmente dura, ya que su actividad económica -basada, como se ha indicado, fundamentalmente en el ámbito del Arsenal- se

10 Archivo Municipal de Cartagena (en adelante, AMCt). Fondo Eduardo Cañabate Navarro (en adelante, FECN). Libro de la Asociación de Jesús Sacramentado.

11 Roda Alcantud 2014: 85.

12 Sánchez Baena 2012: 333-342.

13 Soler 1777: 538-539. En todas las citas textuales se han respetado la grafía y puntuación originales. 
verá paralizada casi totalmente al cesar la llegada de fondos desde la Real Hacienda, a lo que se unirá una serie de epidemias. ${ }^{14}$

Se puede afirmar que la quiebra socioeconómica tomó tintes dramáticos nada más despuntar el siglo XIX. Un patético informe que en el año de 1801 envía el Teniente General de la plaza por vía reservada al propio Rey, pone de manifiesto los graves perjuicios que se originan en la ciudad por la falta de pago de sueldos y jornales, durante meses, a los empleados de la marina de Cartagena:

... decir que las personas de distincion del estado Mayor se ven precisadas á vender sus muebles á vil precio, teniendo que darlos, sin excluir las Alajas de oro, y Plata, por la quinta parte de su valor. que los Pobres honrrados se ven vender en publico hasta sus eslavones, contentandose, aun, con un ochavo para tener algun socorro: Que muchos empleados asi de la Marina, como del Ministerio, salgan de noche á pedir limosna, y otros de dia, llenos de lagrimas, y de pudor, se valgan de la Caridad de algunos honrrados bienechores, para poder alimentar sus familias, siendo notorio que la mayor parte de estas, no tienen otro advitrio para su comun subsistencia, que sus respectibos sueldos, y ultimamente basta decir, que ni aun las cortinas de los balcones estan seguras de las manos de los necesitados. ${ }^{15}$

Este contexto negativo tuvo un punto culminante con la epidemia de $1804 .{ }^{16}$ Se trataba del terrible "vómito negro" del Caribe que pronto se hizo dueño de la ciudad. El Hospital Militar con capacidad para 4.000 enfermos llegó a tener 8.000. Cartagena se declaró epidemiada y un cordón sanitario con centinelas armados la aisló por tierra y por mar. Se desalojaron cuarteles y barcos, y en diciembre había en el Arsenal seis buques desarmados por falta de gente para tripularlos. Al final de la epidemia, en tan sólo siete meses, parece ser que murieron 11.445 personas. ${ }^{17}$ Dicha epidemia recorrió todos los barrios y zonas de Cartagena: «Santa Lucia, callejón de la Guía, calle de la Gomera, barrio de Pescadores, puerta de la Villa, calle de los Gitanos, donde solo quedó indemne un vecino y el Hospital de Caridad». ${ }^{18}$ Durante la misma, se enterraban los cuerpos en grandes zanjas fuera de la Ciudad, no doblaban las campanas ni se hacía ningún funeral, sino que se les amortajaba y se introducían en un ataúd, siéndoles aplicados los sufragios una vez pasada la epidemia.

En este panorama tan adverso se desarrolla la Guerra de Independencia, que no hace más que agravar la delicada

\footnotetext{
14 Roda Alcantud 2011: 106-107.

15 AMCt. FECN. Perjuicios que se siguen por la falta de Pago de Sueldos, Jornales y demas aberes, correspondientes á los Empleados en la Marina de este Departamento. Cartagena, septiembre de 1801. (Manuscrito).

16 El día 10 de septiembre de 1804, comenzó la epidemia en Cartagena, localizándose los primeros casos en la calle de la Concepción y casa de los Cuatro Santos. El 12 de junio de 1804, murió el Jefe de Escuadra Tomas Briant, siendo enterrado en una bóveda de la capilla de Justo Juez, que había bajo la escalera de la Iglesia del Convento de San Leandro.

17 Arejula, J. M. 1806. Breve descripción de la Fiebre Amarilla padecida en Cádiz y pueblos comarcanos en 1800, en Medina Sidonia en 1801, en Málaga en 1803 y en esta última plaza y varias otras del Reyno en 1804. Madrid, citado por Nadal 1984: 115. Por su parte, Rafael Torres Sánchez (1990: 149) da la cifra de unos 8.000 fallecidos.

18 Martínez Rizo 1894.
}

situación. ${ }^{19}$ El Arsenal había quedado prácticamente paralizado y el tráfico marítimo había caído en picado. La población de Cartagena se redujo, en menos de un decenio, de 49.957 habitantes en 1797 (16.735 en el campo y 33.222 en la ciudad) a 35.354, en 1806 (21.708 ciudad y 13.646 campo). ${ }^{20}$ En el padrón de 1813 el total de la población era de 27.569 habitantes (19.695 ciudad y 7.874 en el campo). ${ }^{21}$ Por tanto, en unos quince años hubo una pérdida de unos 14.000 habitantes en la zona urbana y más de la mitad de la población de su campo. La sensación es que Dios había abandonado -¿̇o castigado?-a Cartagena.

\section{PANORAMA RELIGIOSO DE CARTAGENA A INICIOS DEL SIGLO XIX.}

Cartagena contaba con una situación religiosa peculiar. Primera capital de la diócesis, a la que daba nombre, a finales del siglo XIII, ante el peligro berberisco, se decide el traslado de la sede a la ciudad de Murcia. Este hecho lastraría de forma importante el desarrollo religioso de la ciudad. Aunque Cartagena fue cabeza de una vicaría, lo excepcional es que la ciudad contó con una única parroquia, ${ }^{22}$ situación que sólo variará a finales del siglo XIX cuando se fundaron dos parroquias más para atender a la creciente población, tanto de la propia ciudad como de los núcleos rurales circundantes. ${ }^{23}$

De este modo, el servicio religioso quedaba garantizado con una serie de templos que actuaban como anejos de la parroquia y ermitas, ${ }^{24}$ a los que hay que añadir las iglesias de los conventos masculinos con que contaba la ciudad:

que los son uno de Observantes de San Francisco, otro de Santo Domingo, otro de San Agustin, otro de Merzenarios Calzados, otro de Carmelitas Descalzos, otro de San Juan de Dios, otro de San Diego Descalzos de San Francisco, y otro de Minimos de San Francisco de Paula, y a una legua de distancia el de San Gines de la Xara Recoletos tambien de San Francisco. Un Convento de Religiosas Franciscas sugetas a su Religion, y un Collegio de la Compañía de Jesus. ${ }^{25}$

En cualquier caso, existía en la ciudad de Cartagena la sensación de cierto abandono por parte de las autoridades diocesanas, cuya prueba más visible era el estado ruinoso en que se encontraba la antigua catedral. Pero existían otras evidencias notables, como el hecho de que la parroquia durante los primeros años del siglo XIX no contara con un párroco titular

19 Roda Alcantud 2008.

20 AMCt. Estado General de la Población de Cartagena y su Campo (1798). Caja 5, Expediente (Exp.) no 6; y Estado General de la población de Cartagena y su Departamento de Marina (1806). Caja 5, Exp. no 7.

21 AMCt. Caja 5, Exp. no 8. Estado General de la población de Cartagena y su Departamento de Marina. Cartagena, 1813.

22 Como la antigua catedral fue languideciendo poco a poco -por lo que fueron frecuentes los avisos sobre el peligro de ruina en que se encontraba-, hubo de construirse a inicios del siglo XVIII, no sin vencer las reticencias del cabildo catedralicio de Murcia, un nuevo templo: la iglesia de Santa María de Gracia.

23 Robles Muñoz 1987: 82.

24 Egea Bruno, 1991: 272-274.

25 Archivo Secreto Vaticano. Sagrada Congregación del Concilio. Leg. 193B, fols. 38v-39r. Visita ad limina del obispo Diego de Rojas y Contreras, año de 1759, disponible en Irigoyen López y García Hourcade 2001. 
sino que su cuidado quedara a cargo de un cura ecónomo: Bernardino Rolandi. Por todo ello, para referirse a la situación eclesiástica de comienzos del siglo xIX, Pedro María Egea no duda de hablar de una controvertida asistencia pastoral, con una notable desatención hacia los fieles. ${ }^{26}$

En los primeros momentos del conflicto bélico un gran desconcierto asoló Cartagena. La ciudad fue una de las primeras localidades en levantarse contra los franceses y proclamar su fidelidad a Fernando VII como rey. El 23 de mayo de 1808 la multitud, indignada con las noticias que llegaban, se dirigió a la Maestranza, donde los oficiales facilitaron las armas necesarias para la sublevación. ${ }^{27}$ La insurrección popular provocó que algunas autoridades, tachadas de afrancesadas, fueran depuestas y sustituidas por otras que se consideraban más fieles a la causa. Se creó la Junta Particular de Gobierno, cuya máxima preocupación fue la de asegurar la plaza, ${ }^{28}$ empresa que se culminó con éxito pues Cartagena nunca sería violentada. ${ }^{29}$ Sin embargo, continuaba la tensión social, y una muestra es el confuso y dramático suceso acontecido, que enmascaraba la lucha de poder dentro de las élites de Cartagena: ${ }^{30}$ el 10 de junio de 1808, a las seis y media de la tarde, "le quitaron la vida a puñaladas, al Excmo. Sr. D. Francisco de Borja, Cap. Gral., a la Puerta del Arsenal». ${ }^{31}$ Tras estos incidentes, la Junta se ocuparía del gobierno de la ciudad. La peculiaridad de la Junta de Cartagena es que de los dieciocho miembros que la compusieron, doce eran militares de alta graduación, lo que muestra a las claras el dominio del poder militar sobre el civil. ${ }^{32}$

Por otra parte, las cofradías pasionales se resintieron profundamente debido a la crisis de los inicios del siglo XIX. La situación endémica que se produjo en la ciudad dio como resultado la pérdida de muchos hermanos cofrades que son, en definitiva, los que mantenían con su participación y su aportación estas entidades. Este hecho gravaba aún más la precaria situación económica de las cofradías, que ya venía deteriorándose desde finales del siglo anterior, debido a las primeras políticas desamortizadoras. A esto se une que las personas más relevantes de la ciudad, en las cuales se ha demostrado que se apoyaban económicamente estas cofradías, dejaron de intervenir física (fallecimiento o traslado fuera de la ciudad) y materialmente, ya que sufragaban parcial o totalmente la mayoría de las veces los gastos de las distintas funciones o actos religiosos de dichas instituciones piadosas. En esta situación, si bien las procesiones pudieron mantenerse durante el año 1800, a partir de entonces fue cada vez más difícil su realización, por lo que su salida a la calle en los primeros años del siglo XIX fue intermitente, debido a las consecuencias negativas de las epidemias y la Guerra de la Independencia. ${ }^{33}$

Muchas cofradías casi tuvieron que comenzar desde cero, como se desprende de la mayoría de la documentación analizada. Así, por ejemplo, en el informe remitido por

\footnotetext{
26 Egea Bruno 1991: 267-271.

27 Piñar López 1986: 228-235.

28 Gómez Vizcaíno 2007: 30-32; Piñar López 1986: 251-263.

29 Roda Alcantud 2007: 62.

30 Sánchez Baena y Bouzón Calvo 2010: 337-338.

31 AMCt. FECN. Diario del Convento de San Leandro. Orden de San Agustín de la Ciudad de Cartagena. Realizado por Fray Francisco Tomás de Villanueva Vila y Delgado.

32 Piñar López 1986: 235.

33 Egea Bruno 1991: 320-321.
}

la Cofradía de San José, en 1806 al obispo, se ponía de manifiesto «el deplorable estado en que ha quedado esta cofradía con motivo de la epidemia que acaba de experimentarse en esta ciudad y en la que ha fallecido una muy considerable parte de sus moradores». Se intentaba animar, a los pocos cofrades supervivientes "a que se restituya su antiguo establecimiento, admitiendo por cofrades a cuantos quisiesen serlo, y en quienes concurran las calidades prevenidas por sus constituciones» ${ }^{34}$.

Algo similar ocurrirá con la Archicofradía del Rosario, que no comenzará a recuperarse hasta 1807: «restablecida ya de la decadencia que ha padecido por la calamidad de la epidemia y circunstancia de los tiempos».. ${ }^{35}$ Otra Cofradía, la del Socorro, pone de manifiesto, a través de una carta de su sacristán Juan Bautista Espinosa al mayordomo Fulgencio Posadas, la lamentable situación de la hermandad y la inexistente actividad de la misma desde finales del siglo XVIII, ya que

..desde el mismo día en que la Excma. Sra. Duquesa dejó de ser su patrona, pagar las pensiones, faltar los ministros nombrados por su Excma. y no cumplirse más que dos o tres artículos de sus santas constituciones; y sí solo, un número de caballeros congregantes que fueron nombrados y recibidos cuando existía la ilustre cofradía, que llenos de celo y devoción, procuran el culto al Señor por su parte en cuanto pueden para sostenerlo. ${ }^{36}$

La Guerra de la Independencia, por tanto, parecía que dejaba poco espacio a las cofradías: «Llega el año ocho y concluyen por completo; el amor a la independencia de la patria absorbió, por completo la atención de todos», como señaló el cronista oficial de la ciudad en segunda mitad del siglo XIX, Manuel González. ${ }^{37}$

\section{AUTORIDADES LOCALES Y RELIGIÓN EN EL CONTEXTO DE LA GUERRA DE LA INDEPENDENCIA}

La sensación de abandono por parte del obispado, las dificultades de la beneficencia y la crisis de las cofradías perturbaban la vida de la ciudad, por lo que las autoridades políticas locales asumieron que los asuntos religiosos también eran competencia suya. De este modo, incluso velaban para que se cumplieran los preceptos católicos, tal y como se puede comprobar en el bando dictado por el gobernador político y militar de la plaza, Francisco de Borja, en 1806:

Que ninguna persona profiera blasfemias contra el Santo Nombre de Dios, su Santisima Madre, Santos y cosas Sagradas, ni tampoco causar irreverencias ni escándalos con votos y juramentos, y con el uso de palabras, acciones o cantares deshonestos; cuyo delito se castiga con la severidad impuesta por las leyes, y por de contado con la multa de dos ducados, si fuera de Estado Noble, y quince días de cárcel siendo del estado llano. ${ }^{38}$

\footnotetext{
34 Libro de cabildos de la Cofradía de San José. Acta de 20 de Febrero de 1806, fols. 34v-35r, citado en Egea Bruno 1991: 305.

35 Diario de Cartagena, 2 de Mayo de 1807, citado en Egea Bruno

36 AMCt. Caja 311. Culto y Clero. "Carta dirigida al mayordomo de la cofradía del Cristo del Socorro, D. Fulgencio Posadas, por el sacristán de la misma, D. Juan Bta. Espinosa”. Cartagena, 20 de Marzo de 1806, citado en Egea Bruno 1991: 305.

37 BSI. El Eco de Cartagena. Miércoles 9 de abril de 1879.

38 AMCt. Caja 466. Régimen interior y ordenanzas municipales. Bando de Buen Gobierno. Cartagena, 1806, citado en Egea Bruno 1991: 283.
} 1991: 305. 
Se puede apreciar claramente cómo las autoridades participaban en el control religioso. El poder civil en apoyo de la doctrina católica, los pecados convertidos en delitos. En este ámbito conviene no olvidar que las blasfemias fueron cometido del Santo Oficio de la Inquisición. A fin de cuentas, la religión era un asunto de Estado, como podía comprobarse en la política regalista de los Borbones. ${ }^{39}$ En efecto, a partir de la firma del Concordato de 1753, hubo un indisimulado intento de construir una iglesia nacional, a modo de la iglesia galicana, lo que habría de conducir al control político del clero hasta convertirlo en una especie de funcionariado eclesiástico..$^{40}$ Lograrlo pasaba, indefectiblemente, por el apoyo de un episcopado igualmente controlado y puesto al servicio de la política reformista. ${ }^{41}$

Sin embargo, estas intenciones habrían de chocar con gran parte del clero, que pronto identificó regalismo con Ilustración puesto que, como bien indicaba François López, el estamento eclesiástico español era uno de los más reacios a cualquier cambio y su saber era el más arcaico de Europa. ${ }^{42}$ De este modo, fueron más numerosos los clérigos que se opusieron a la difusión de las Luces y, por extensión, a la política de reformas regalistas, lo que se tradujo en la aparición de un cierto pesimismo entre las filas religiosas. ${ }^{43}$ La Revolución Francesa, la Guerra de la Convención y, por último, la invasión napoleónica, fueron circunstancias que, además de marcar los inicios del proceso de desarticulación de la Iglesia, ${ }^{44}$ sirvieron para ratificar, consolidar y radicalizar esta posición eclesiástica, germen del pensamiento reaccionario hispano..$^{45}$

En la España de finales del siglo XVIII y principios del XIX, política y religión caminaban unidas, por tanto. Con todo, el clero no formaba un grupo monolítico, sino que se pueden descubrir en su interior, por resumir, al menos tres tendencias durante este periodo: ilustrados, afrancesados y tradicionalistas. ${ }^{46}$ No es difícil adivinar con qué hay que vincular a cada uno de estos grupos: con las Cortes de Cádiz, la monarquía josefina y la monarquía absolutista de Fernando VII, respectivamente. Sin embargo, el primer y segundo grupo compartían los ideales de reforma, en especial lo relacionado con el clero regular, pero diferían de la forma lograrlo. Igualmente las fronteras entre el primero y el tercer grupo fueron difíciles de establecer durante la Guerra de la Independencia, ya que ambos se oponían a la monarquía de José I; sólo tras la redacción de la Constitución de 1812 y, sobre todo, con el retorno de Fernando VII, la situación quedó clarificada y los caminos, separados. Para entonces se ratificó lo señalado un poco más arriba: que la mayoría del clero apoyó la alianza Altar-Trono, con la consecuencia de que el liberalismo pasaría a ser el nuevo enemigo. Al fin y al cabo, durante la Guerra de la Independencia, los eclesiásticos se emplearon con ardor en defensa de la Monarquía y la Iglesia, la cual en aquellos momentos era la única auténtica organización nacional. ${ }^{47}$

\footnotetext{
39 Egido 1979; Artola Renedo 2013.

40 Calvo Maturana 2011: 169-192.

41 Domínguez Ortiz 1976: 371.

42 López 1987-1988: 795-800.

43 Martínez Albiach 1969: 399.

44 Andrés-Gallego y Pazos 1999: 68-73.

45 Herrero 1988: 22-24.

46 Alonso 2014: 23-41.

47 Castells 1973: 59-60.
}

En cuanto la situación fue volviendo a la normalidad, se restauraron las prácticas cotidianas de la población; eso incluía, como es lógico, las actividades religiosas. De este modo, el día 30 de mayo de 1808 se realizó la novena que tenía que haberse celebrado en honor a Santa Rita el día 23 de mayo, que tuvo que suspenderse debido al "primer motín de Cartagena". ${ }^{48}$

Por otro lado, el día 14 de junio de 1808 bajaron a los Cuatro Santos en procesión de rogativa por la guerra contra los franceses, asistiendo las comunidades y el pueblo. Las imágenes fueron situadas en el presbiterio de la Iglesia Mayor de Cartagena, y al lado del Evangelio se colocó a la Virgen del Rosel, acordándose que cada día fuera una comunidad a cantar misa ${ }^{49}$.

Las celebraciones religiosas demuestran el activo papel que se quiso dar durante la contienda bélica al catolicismo como factor aglutinante de los sentimientos patrióticos, tal y como señala Fraser..$^{50}$ La alianza Altar-Trono fue una realidad palpable, asumida plena y conscientemente por las autoridades de la Junta de Cartagena porque se pensaba que favorecer a la religión era favorecer al Rey y a la Nación. Lo que coincidía con los pensamientos de la Junta Central, que estaba convencida de que la ruina de la Patria acarrearía la de la religión, pues, como señala Manuel Revuelta, persistía la concepción religiosa del Antiguo Régimen de que sin religión no sería posible la sociedad, la Patria ni el Estado. ${ }^{51}$

Evidentemente, todo esto partía del discurso eclesiástico que había ido calando en la población española desde los últimos años del siglo XVIII, cuando la Iglesia desplegó una campaña de propaganda sin igual contra las "novedades" que venían de Francia. ${ }^{52}$ Los instrumentos utilizados fueron los que más genuinamente empleaba el clero del Antiguo Régimen: los sermones, los tratados, las misiones populares, las cartas pastorales, el confesionario... De este modo, se fue extendiendo la idea de que la religión y el clero, por supuesto, eran elementos esenciales de la vida social y política, garantes, al fin y al cabo, del orden establecido. Desde estos presupuestos no resultó difícil otorgar un carácter sagrado a la Guerra de la Independencia, ${ }^{53}$ que pronto fue una guerra ideológica, ${ }^{54}$ una cruzada contra la impiedad de los hijos de la revolución. ${ }^{55}$ Como indicara Martínez Albiach, la guerra divinal pertenecía a la esencia de la católica España: ${ }^{56}$ "La guerra santa española será el principio de una cruzada por la que estas fuerzas del mal son vencidas, y la Iglesia y la Monarquía absoluta, restauradas a su pasada grandeza». ${ }^{57}$

Por consiguiente, en la España de fines del Antiguo Régimen la religión era un asunto de dominio público y fue utilizada y manipulada con fines políticos. ${ }^{58}$ De este modo, las

48 AMCt. FECN. Diario del Convento de San Leandro. Orden de San Agustín de la Ciudad de Cartagena. Realizado por Fray Francisco Tomás de Villanueva Vila y Delgado.

49 Ídem.

50 Fraser 2006.

51 Revuelta González 1979: 9.

52 Herrero 1988: 27-45 y 230-237.

53 Ibídem: 245-256.

54 Martínez Ruiz y Gil 2010.

55 Revuelta González 1979: 9.

56 Martínez Albiach 1969: 80.

57 Diario Político de Mallorca, 4 de julio de 1808, citado en Martínez Ruiz y Gil 2010: 187.

58 Revuelta González 2009: 232-246. 
autoridades político-militares de Cartagena, que ya se ha visto se ocupaban de ello, ahora en este periodo de conflicto bélico redoblaron su intervención pues religión, nación y rey eran uno. Basta con leer cualquiera de las versiones que se hicieron del Catecismo civil publicado en 1808, pocos días después del levantamiento en Cartagena, donde queda constancia de las motivaciones de la guerra santa contra los franceses:

...haciendo saber á la Europa y al Mundo, el vil proceder de este infame aliado, que ha saqueado nuestros pueblos, robado los vasos sagrados de nuestras iglesias, profanado los misterios de nuestra santa religión, ultrajado á nuestros sacerdotes, y quitado la vida á innumerables inocentes. ${ }^{59}$

Por todas partes, las pastorales, sermones, oraciones y acciones litúrgico-patrióticas calaron en la población española. ${ }^{60} \mathrm{El}$ catolicismo debía incrementar su presencia en la vida local porque encendía el sentimiento patriótico. Una consecuencia directa de la guerra vendría a favorecer este anhelo en Cartagena: el refugio de varios obispos en la ciudad.

Como es bien conocido, al inicio de la contienda el episcopado adoptó diferentes actitudes, ${ }^{61}$ síntoma de esa división del clero a la que se ha aludido un poco más arriba. ${ }^{62}$ En efecto, algunos prelados, los menos ciertamente, decidieron colaborar con la monarquía josefina. ${ }^{63}$ El resto de los obispos fueron abandonando sus diócesis según avanzaba el ejército francés. ${ }^{64}$ Varios de estos prelados llegaron a Cartagena: además del titular de la diócesis, José Ximénez, también se refugiaron en la ciudad departamental, los obispos de Almería, Guadix, Calahorra y Almería. ${ }^{65}$ Pero se dio la circunstancia que el prelado de la diócesis de Cartagena decidió exiliarse, junto con otros obispos, a la isla de Mallorca, ${ }^{66}$ hecho que produjo un profundo descontento en la ciudad, tal y como se puede comprobar en las quejas por parte de la Junta de Observación y Defensa. ${ }^{67}$

El exilio episcopal se tradujo en cierta desorganización eclesiástica, y muchas juntas locales también pasaron a ocuparse de cuestiones religiosas. Un buen ejemplo de esto es Cartagena, incluso contando con la presencia del obispo. Por esta razón, cualquier iniciativa que pasara por el fomento de la religión católica, sería bien recibida por la Junta.

¿Sólo por la Junta? No, realmente. Es todo el grupo oligárquico el que se va a implicar en esta misión, en la cual los miembros de la Armada van a adquirir un protagonismo evidente. Al mismo tiempo, al obrar de esta forma, los grupos dominantes conseguían otro objetivo no menos importante: poner la religión (o al catolicismo o la Iglesia) al servicio de sus propios intereses, que no eran otros que mantener su influencia en todos los asuntos de la vida local y asegurar su

\footnotetext{
59 Catecismo civil de España en preguntas y respuestas, mandado imprimir de orden de la Junta Suprema. Sevilla: por la Viuda de Hidalgo y Sobrino, sin fecha: 5.

60 Revuelta González 1979: 10

61 Barbastro Gil 2013: 21-31.

62 Artola Renedo 2013: 265-282.

63 Moreno Alonso 2014: 180-226. Véase igualmente Artola Renedo 2014 y Barrio Gozalo 2007.

64 Callahan 1989: 89-90; Barbastro Gil 2013: 35-52.

65 Asimismo pasaron por la ciudad de Murcia los citados obispos de Guadix y Calahorra, a los que hay que añadir los de Tortosa y Burgo de Osma (Candel Crespo 2003: 33-42).

66 Revuelta González 1979: 27.

67 Casal 1910:85-87.
}

perpetuación en el poder. Al fin y al cabo, la religión ofrecía indudables atractivos: además de ser un fenomenal instrumento de control social, constituía un formidable escaparate para una oligarquía, cada vez más vinculada a la Armada. De este modo, era este cuerpo militar el que pasaba a ejercer una notable influencia en la vida religiosa de la ciudad -que habría de perdurar en el tiempo-, más si se tiene en cuenta que en el momento histórico del primer liberalismo, la religión constituía para la mayoría de las personas una realidad mental mucho más importante que la política. ${ }^{68} \mathrm{~A}$ fin de cuentas, como señalan José Andrés-Gallego y Antón Pazos, el catolicismo español de comienzos del siglo XIX era una realidad unánime. ${ }^{69}$ Dos hechos, acaecidos en una coyuntura especial como fue la Guerra de la Independencia, vendrían a facilitar este empeño de la Armada: la creación de la Asociación de Jesús Sacramentado y la instalación de la parroquia castrense en la iglesia del convento de Santo Domingo. ${ }^{70}$

\section{LA ASOCIACIÓN DE JESÚS SACRAMENTADO}

En el contexto bélico se crea la Asociación de Jesús Sacramentado. Es interesante conocer esta institución por cuatro razones fundamentales: una, porque la historiografía que estudia los aspectos religiosos de estos años de invasión apenas se centra en el análisis de la realidad religiosa local, salvo algunas excepciones; dos, porque es un pasaje no demasiado conocido de la historia de Cartagena que desprende e ilustra una parte muy interesante de la ciudad actual. Tres, porque se trata de una institución que puede considerarse bisagra: si bien se incluye entre los precedentes de unas formas de piedad que se generalizarán bien entrado el siglo XIX, al mismo tiempo enlaza con las del Antiguo Régimen, pues no en vano, el misionero fray José Diego de Cádiz fue el principal valedor de un culto eucarístico que se difundiría cada vez y que cristalizaría en la fundación, a instancias de fray Jerónimo de San Eliseo, de la Real Congregación del alumbrado y vela al SS. Sacramento del Altar, establecida en la capilla real en $1789,{ }^{71}$ con el fin de que dicho culto se propagara por el conjunto de la Monarquía, como así sucedería, surgiendo corporaciones de este tipo en numerosas ciudades desde finales del siglo XVIII. Y cuatro, porque servirá de inspiración a otras asociaciones similares, como la Congregación de vela y alumbrado del Santísimo Sacramento, fundada en Murcia en 1817 por el obispo José Ximénez, ${ }^{72}$ cuyas constituciones serían aprobadas por Fernando VII ese mismo año, las cuales son muy similares a las de Cartagena. ${ }^{73}$

\footnotetext{
68 Faria, A. Mouta 2014: 142.

69 Andrés-Gallego y Pazos 1999: 15.

70 Soler Cantó 1988: 65.

71 Real Congregación del alumbrado y vela al SS. Sacramento del Altar establecida en la capilla del palacio real... Madrid: Imprenta Real, 1790.

72 Vilar García 2008: 819-820.

7 Real Cédula de S.M. y señores del Consejo por la qual se aprueban la Congregación y constituciones de Vela y Alumbrado del Santísimo Sacramento que canónicamente se ha erigido en esta ciudad de Murcia, año de 1817. Murcia: por los herederos de Muñiz, disponible en Biblioteca Virtual del Patrimonio Bibliográfico: http://bvpb. mcu.es/es/consulta/busqueda_referencia.cmd?posicion=1\&idValor=3 29142\&forma=ficha\&id=1271
} 
En los años tan difíciles de la Guerra de Independencia fue cuando se puso en marcha la Asociación de Jesús Sacramentado de Cartagena. Su antecedente se encuentra en el siglo XVIII, cuando existía la archicofradía del Santísimo Sacramento, y comparte con ella varios aspectos. ${ }^{74} \mathrm{El}$ cometido principal de aquélla era correr con el gasto de cera, ya cuando salía el viático a visitar a los enfermos, ya en la procesión del Corpus. Otra de las actuaciones era igualmente costear las visitas a las ayudas de parroquia de la ciudad con sacerdotes, escribanos de número y procuradores. Dicha archicofradía se sabe que todavía estaba en activo en 1802, según se desprende del inventario de bienes de José Mendoza, hermano de la Cofradía de Jesús Nazareno, donde se otorga «una libra de zera labrada o su valor a la Archicofradia del Santisimo Sacramento de esta Ciudad». ${ }^{75}$ Por consiguiente, la asociación se inscribe en toda una tradición en una ciudad donde las cofradías tenían gran predicamento, aunque en este período, como se ha visto, no pasaban por su mejor momento, ${ }^{76}$ algo común a toda España. ${ }^{77}$ De ahí que para referirse al periodo que va desde el inicio de las reformas ilustradas en el reinado de Carlos III, inicio de la campaña contra ellas, ${ }^{78}$ hasta el último tercio del siglo XIX, en que se asiste a una explosión de las cofradías procesionales, se hable de "oscuro siglo cofrade". ${ }^{79} \mathrm{Al}$ mismo tiempo, se beneficia del ambiente propicio de nuevas devociones, como la del Sagrado Corazón, con la que guarda ciertos paralelismos, en especial la participación de las élites sociales. ${ }^{80}$ Vinculada en sus inicios a mediados del siglo XVIII con la Compañía de Jesús, la expulsión de los jesuitas detuvo un poco la marcha ascendente de esta devoción, la cual se desarrollaría de forma exponencial durante el siglo xIx. De este modo, en la ciudad de Murcia en 1827 se fundaría la Real Congregación del Sagrado Corazón de Jesús en el convento de Justinianas de Madre de Dios, que vendría a tomar el relevo de la establecida en el colegio de los jesuitas en $1752 .{ }^{81}$

Pero la asociación tiene rasgos novedosos que la vinculan con las que habrían de generalizarse en la segunda mitad del siglo XIX. De hecho en el último tercio la Iglesia procede a la recuperación de una época a través del asociacionismo. ${ }^{82}$ A diferencia de lo que sucedía antes, ${ }^{83}$ el nuevo

74 Desde el siglo XVı existía en Cartagena la cofradía del Santísimo Sacramento vinculada al Gremio de la Pesquera (Montojo Montojo y Cobarro Jaén 1991: 70-83).

75 ACJN. Caja 31, carpeta 3 (Fotocopia del original). Ymbentario aprecio, y Particion de los Bienes que han quedado por el Obito de Dn. Josef Mendoza, Maestro mayor de Armero que fue del RI. Cuerpo de Cavalleros Guardias Marinas, de este Departamento. Cartagena. Año de 1802.

76 Egea Bruno 1991: 290-321.

77 Cortés Peña y López-Guadalupe 2010: 34.

78 Arias de Saavedra y López-Guadalupe Muñoz 2002.

79 Marín Cano 2008: 159-177.

80 Vinculada en sus inicios a mediados del siglo XVIII con la Compañía de Jesús, la expulsión de los jesuitas detuvo un poco la marcha ascendente de esta devoción, la cual se desarrollaría de forma exponencial durante el siglo XIX (Herradón Figueroa 2009: 194-196).

81 Candel Crespo 1981: 23-27 y 43-52.

82 Castells 1973: 221

83 Maruri ha constatado que dentro del conjunto de las advocaciones en la Cantabria occidental entre los siglos XVIII y XIX, las advocaciones de Cristo sólo representaban el 6,6\% del total; y dentro de ese porcentaje, las advocaciones de gozo (Niño Jesús, Nombre de Jesús, Salvador, Transfiguración y Santísimo Sacramento) eran minoritarias pues únicamente reunían el 27\% (Maruri 2014: 178). ambiente conllevaba una piedad centrada en Jesucristo, que se concretaría en la devoción a su pasión, a su eucaristía; de ahí el resurgir del Sagrado Corazón. ${ }^{84}$ Varios testimonios de esta nueva actitud se pueden encontrar como, por ejemplo, en el convento de Santa Clara de la ciudad de Murcia, en torno al que se crearía la asociación de Hijas de María en Murcia y se fomentaría el culto eucarístico. ${ }^{85}$

Por otra parte, entre los promotores que estaban detrás de la creación de las asociaciones religiosas, con frecuencia se encontraban los grupos dominantes. En el Antiguo Régimen, en ocasiones respondían a acciones de gracias por parte de individuos concretos tras superar situaciones adversas, como es el caso de la cofradía del Cristo del Socorro, fundada en Cartagena a fines del siglo XVII por el duque de Veragua. ${ }^{86}$ Otras veces surgían, siguiendo los orígenes medievales, como corporaciones que representaban a grupos socioprofesionales o gremios, tal es el caso de la cofradía de Nuestro Padre Jesús Nazareno, fundada por los pescadores de Cartagena. ${ }^{87}$ Otras se caracterizaban por su horizontalidad, ya sea nutriéndose de los integrantes de un mismo estamento, como por ejemplo, la citada cofradía del Cristo del Socorro de Cartagena, compuesta únicamente por nobles, ${ }^{88}$ ya de naturales de una misma nación como la Hermandad y Hospital de San Antonio de los portugueses de Madrid. ${ }^{89}$ Por otro lado, Vicente Montojo señala que fue el grupo urbano intermedio de la ciudad de Murcia el que protagonizó la refundación de las cofradías pasionarias en los siglos XVII y XVIII, puesto que en la Cofradía de Jesús eran escribanos, abogados y procuradores, a los que muy pronto se incorporarían miembros de la pequeña nobleza, quienes ocupaban los cargos principales, ${ }^{90}$ a los que habría que unir clérigos seculares. ${ }^{91} \mathrm{Y}$ otras asociaciones, en fin, servían a las familias de las oligarquías locales para hacer manifestación de su prestigio social, como podía ser la cofradía de la Inmaculada de Murcia. ${ }^{92}$

Fue durante un encuentro fortuito a finales del año de 1809 entre unas feligresas y un fraile del convento de San Diego, cuando comience a gestarse la posibilidad de poner en marcha la citada Asociación de Jesús Sacramentado. Va a ser el propio impulsor de la idea, el citado hermano, cuyo nombre era Jerónimo Navarro, el que recoja detalladamente en el Libro de la asociación todas las vicisitudes que acontecieron hasta su puesta en marcha:

En uno de los mas proximos dias á la Pasqua de Navidad del año 1809 encontré (...) á Dạ Clemencia la Torre con Dạ Tercia y Dạ Francisca del Valle en la Plaza de la Verdura que venian de Misa de la Iglesia de San Agustín y acercandose a mi me dijeron: -la Sa Capitana Generala es muy buena y devota del Santisimo Sacramento y tiene grandes deseos de que se manifieste en Cartagena todos los dias de fiesta y ya tiene hablado con algunos Señores que van a la casa, de modo que tiene algunos a su bando, y otros no la han buelto respuesta y usted nos tiene dicho

84 Jiménez Duque 1979.: 415-417.

85 Vilar y Vilar García 2012: 382-385.

86 Carralero Alarcón y Espín García 2009: 27-44.

87 Maestre de San Juan y Montojo Montojo 1999: 13-18.

88 Fernández Araujo 1999: 38.

89 Pulido Serrano 2004.

90 Montojo Montojo 1993: 3.

91 Montojo Montojo 2011: 270-272.

92 Vilar García 2008: 818. 
que se determina a manifestar al Santisimo Sacramento todos los dias por un modo facil sin gravar al Pueblo ¿por que no va usted a verse con la Señora para darnos ese consuelo?- y yo respondi a las Señoras que no tenia entrada en la casa y no conocia a la Señora Generala y para hablar con estos Señores era necesario tener algun conocimiento, y que asi lo que podian hacer era sacarme en conversacion en la visita para que yo pudiese meter la cabeza, que en entrando la cabeza todo el cuerpo entraria, pues mis deseos de que se manifestase al Santisimo Sacramento ya los sabian y tenia mis cuentas bien hechas por un cierto modo para que se hubiese manifiesto todos los dias con Sermon por las tardes sin gravar al Pueblo pues todos estarian gustosos y contribuirian para los gastos sin hacerles falta para el alimento de sus familias...93

A continuación, el fraile se dirigió a la casa del notable Antonio Quesada, cuya esposa Encarnación de Santa María, también era una gran devota de dicha manifestación. De la narración del franciscano se infiere que mantuvo una charla sobre el tema del Santísimo, pero sin citar la conversación que había tenido horas antes. La principal preocupación del fraile era la búsqueda de apoyos entre la gente principal de la ciudad, por lo que debía poner en funcionamiento todas sus habilidades para entusiasmar sobre la empresa, tal y como se corrobora en su propia narración:

... al despedirme [la citada señora] se echó de pechos sobre la baranda de la escalera, habiendo yo bajado algunos escalones, me dijo -Hermano Geronimo ¿Por qué no hace usted de modo que tengamos manifiesto todos los dias? pues yo estoy pronta a contribuir con la parte que me toque..$^{94}$

Es evidente que era la pregunta que él esperaba, y en la que había trabajado durante la visita. La ocasión que él había preparado, no la desaprovechó, y fue en este momento cuando le relató la conversación que había tenido con las citadas feligresas, pero insistió en que «me faltan las fuerzas y un brazo fuerte que me ayude que entonces yo lo haré turnando por las Iglesias sin gravar al Pueblo». La tal Da. Encarnación le respondió con las mismas palabras que las anteriores feligresas:

...que por que no hablaba con la Capitana Generala que era muy buena y devota", a lo que le respondió -milimetricamente otra vez- "que no la conocia y asi que me sacase en conversación en la visita que ya se lo habia encargado tambien a Da. Clemencia la Torre y a las Sras. del Valle. ${ }^{95}$

Es más que probable que el hermano Jerónimo llevara tiempo con la idea de sacar el Santísimo a diario, y que aprovechó las informaciones que iba recabando para lograr un apoyo importante que permitiera llevarla a cabo, dada la situación económica tan difícil por la que atravesaba la ciudad, la invasión napoleónica y su falta de contactos al más alto nivel, ya que él era solamente un profeso más de los franciscanos descalzos. Dichas conversaciones surtieron efecto, y a los pocos días tenía una invitación para acudir "sin falta ninguna" a la casa del Capitán General, que en esos momentos era Manuel Núñez Gaona. ${ }^{96} \mathrm{El}$ siguiente

93 AMCt. FECN. Libro de la Asociación de Jesús Sacramentado: fol. 3.

94 Ibídem: fols. 4-5

95 Ibídem: fol. 5.

96 Fue Capitán General del Departamento entre junio de 1809 y mayo de 1812. paso que dio el hermano Jerónimo fue el de informar en su convento a su padre guardián, fray Tomás Gaytán, quien le dio licencia y aprobación para que siguiera adelante.

Una vez en casa de la "Capitana Generala" y después de hablar un buen rato, el hermano Jerónimo entró en materia:

Señora yo me determino a que en Cartagena se manifieste el Santisimo Sacramento todos los dias por un modo facil y sin gravar al Pueblo porque yo recurriré á sus vecinos y estos muy gustosos me contribuiran para los gastos, esté V.E. de mi parte y se cumplirán todos nuestros deseos porque estando V.E. de mi parte y yo de parte de V.E. lograremos lo que pretendemos. ${ }^{97}$

Seguidamente pasó a explicarle de que manera podría conseguirse dicho objetivo, su propuesta se resumía en dos fines concretos:

... que se manifieste el Santisimo Sacramento y que quando salga en viatico para los enfermos sea con doce luces y tambien que se hagan unos altares portatiles para los que no tengan en su casa con que hacer altar (...) porque en la irrisión de los Libertos Herejes el ver a un mismo Dios para unos con varias luces Achas y para otros con dos faroles como quien alumbra a un muerto; tambien es dolor que muchos pobres infelices no tienen para un puchero y tendidos en un gergon de paja en el suelo, quando se le va á suministrar el Santisimo Sacramento tienen que buscar entre los vecinos para un par de velas de a real que son dos candelillas y este pobre se empeña en estos dos reales y á JesuChristo no le dá en culto que nosostros podemos darle por este medio. ${ }^{98}$

El fraile, consciente del importante apoyo que se le estaban dando, en su despedida, y delante de la autoridad militar, aseveró lo siguiente: "ya quedamos acordes y veremos por quien queda pues por mi no ha de quedar veremos á ver si V.E. está de mi parte como yo de la de V.E.». A lo que fue respondido: «cuidado hermano Geronimo que esta casa la tiene $\mathrm{Vd}$. a su disposicion que no deje Ud. de venir y buen animo $"{ }^{99}$ Es evidente que una de las cuestiones más importantes para el éxito del proyecto, como era la implicación del máximo poder militar de la ciudad, ya lo había conseguido. Quedaba ahora la tarea, no menos difícil, de sumar a las restantes órdenes de la ciudad y al párroco, mientras que el último escollo que había que salvar era obtener el visto bueno definitivo del obispo.

Aquí comienza lo destacable: el hermano Jerónimo lo habría de hacer, siguiendo las directrices y los contactos que los componentes de las elites religiosas y militares de Cartagena determinaran. De este modo, desde la casa del Capitán General salen las primeras instrucciones: «Pues hermano Geronimo a trabajar, véase Vmd. con el Prior de Santo Domingo y dígale Vmd. que yo le embio, entró a este tiempo el Exmo. Sr. Don Joaquín de Cañaveral ${ }^{100}$ y aprobó los pensamientos». ${ }^{101}$

Es interesante constatar la estrecha relación que unía al Capitán General y su mujer con el prior de Santo Domingo.

97 Ibídem: fol. 6.

98 Ibídem: fol. 7.

99 Ídem.

100 Era en esos momentos teniente general y había ocupado desde 1801 en varias ocasiones el cargo de Capitán General del Departamento, la última vez entre julio y septiembre de 1807.

101 Ídem. 
Tanta que, al final, se puede decir que la asociación se fundará gracias al trío que formaron la Capitana Generala, el prior de Santo Domingo y el hermano Jerónimo, quién sería el encargado de llevar adelante la empresa:

Hermano Geronimo, el Capitán General, la Capitana General y yo [el prior de Santo Domingo] estamos con los brazos amarrados y yo le respondí: pues ya los tienen Vmds. desamarrados, ya está aquí el Hermano Geronimo, vamos a manifestar el Santisimo Sacramento y no tengan Vmds. cuiado. ${ }^{102}$

Según narración del propio fraile, salió inmediatamente a la calle y comenzó a apuntar algunos conocidos, diciéndoles «que iba á establecer una hermandad del Santisimo Sacramento manifiesto que seria perpetua para toda la vida», obteniendo una respuesta más que favorable:

Se dibulgó de tal modo que hoy mismo muchos vecinos de esta Ciudad me buscaban por las calles y algunos iban á buscarme al Convento para quedar apuntados, ofreciendome limosnas mensuales que yo mismo tenia que rebajarlas por parecerme excesivas. ${ }^{103}$

La primera que le pidió que saliese el Santísimo para visitar a los enfermos fue la mujer de Cayetano Momplet, armero de Brigadas, a lo que le contestó el fraile «que tendrían el gozo de verlo con doce luces generalmente para el pobre y para el rico pues este era el fin a que me dirigía igualmente que á manifestar todos los días de fiesta». ${ }^{104}$

De esta manera, comenzó a dar los primeros pasos para la inscripción de todos aquellos interesados. La primera asociada fue $D^{a}$. Antonia Alarcón, contribuyendo con una peseta mensual, a la que siguieron no pocas suscripciones. ${ }^{105}$ Según la narración del fraile, por tanto, se obtuvo un gran éxito. Pero esto hay que tomarlo con precaución, dado el fuerte carácter propagandístico que adquiere el texto. Quizás obedezca más a un deseo que a la realidad, porque de lo que se trataba era de resaltar el carácter popular de la empresa, la existencia de una igualdad, de una comunidad de intereses, entre pobres y ricos.

Asunto delicado era la elección del depositario de las limosnas. El hermano Jerónimo actuó de manera hábil, indicando al prior de Santo Domingo, que él no quería esa responsabilidad y proponía a «mi compadre D. Francisco Millau Comandante de Brigadas», lo que se aceptó sin problema. Por su parte, el prior de Santo Domingo pidió al fraile que se viese «con el Sr. D. Antonio Muñoz Mayor de Brigadas, y con el Sr. D. Joaquín Bilbao, Mayor de Marina, que estos era muy buenos operarios». ${ }^{106}$

El prior de Santo Domingo diseñó la estrategia final para llevar a buen puerto la asociación, ya que indicó al fraile franciscano que debía hacerse una junta de prelados. En la citación debía aparecer que era por «disposición de la Junta Superior de Observación y Defensa de esta plaza». La reunión se celebró y todos aceptaron participar ofreciendo sus iglesias y comunidades. El problema surgió a la hora de redactar la solicitud al obispo para que aprobara

\footnotetext{
102 Ibídem: fol. 8

103 Ídem.

104 Ibídem: fol. 10.

105 Ídem.

106 Ibídem: fols. 10-11.
}

la creación de la asociación, pues había desacuerdo sobre los promotores del proyecto. El prior de Santo Domingo, en su línea de aunar todos los poderes locales, pensaba que "lo iba a hacer en Cabeza del Pueblo y las Comunidades», pero los otros religiosos querían que sólo fuese en cabeza las Comunidades.

Para vencer esta dificultad, el prior mandó al hermano Jerónimo que avisara a la Capitana Generala. Ésta le dijo que había que convocar una nueva reunión, esta vez en su casa, y a la que debían acudir el cura, el prior de Santo Domingo, el guardián de San Diego y el alcalde mayor. Al final, los que firmarían el memorial que fue presentado al obispo en Murcia por el hermano Jerónimo, serían:

- Manuel Núñez, Capitán General del Departamento.

- Gabriel Ciscar, Gobernador de la Plaza de Cartagena.

- José Flores Varela, Intendente de Marina.

- Bernardino Rolandi, Cura de la Parroquial.

- José de Alcaraz de Rosique, Vicario de Marina.

- Fr. Diego de Aguilar, Prior de Santo Domingo.

- Pablo del Villar, Síndico Personero de la Ciudad. ${ }^{107}$

En dicha reunión, se aprobó el memorial en los términos que quería el Padre Prior:

... Penetrado su vecindario de sentimientos tan religiosos y nobles y siendose a iguales deseos de los respetables Cuerpos de Marina, Exercito y Politico de este Departamento, recurrimos a V.S.Y presentandole la justa solicitud de que se les conceda que en todos los dias de obligacion de Misa, se ponga de manifiesto el Señor Sacramentado en todas las Iglesias de esta Ciudad por turno, desde la hora de la 8 de la mañana en la actual estacion y la de la 7 en el verano hasta ponerse el sol, para cuya catolica idea se hallan prontos y conformes la Parroquial y Comunidades deseosas de unir sus auxilios sin el menor interes para el vecindario y demas cuerpos los proporcionará para el decoroso reverente culto. ${ }^{108}$

Así, con fecha 4 de enero de 1810 se daba el decreto de constitución y dos días más tarde se ponía en marcha la citada asociación. El Capitán General nombró los primeros vocales de la Junta de la asociación:

- Sr. D. Marcelo Spinola, Brigadier de la Real Armada.

- Sr. D. Francisco Millau, Comandante del Real Cuerpo de Artillería de Marina.

- Sr. D. Antonio Muñoz, Sargento Mayor del mismo.

- Sr. D. Joaquín Bilbao, Sargento Mayor del 5o de Marina

- Hermano Jerónimo Navarro. ${ }^{109}$

Después Bernardino Rolandi, cura y vicario de esta ciudad, y el padre prior de Santo Domingo presentaron un oficio a la Junta Superior de Observación y Defensa, solicitando que se nombrase la junta directiva; la Junta contestó que lo podían hacer ellos dos, por lo que nombraron a José Reusán, presbítero, y fueron reelegidos los cinco presentados por el capitán general. Posteriormente, se escribió a la Junta para que nombrase presidente y contestó que lo eligiesen los seis vocales, y así nombraron al prior de Santo Domingo. La junta elaboró las constituciones de la asociación, las cuales se presentaron a la Junta de Observación y Defensa, que las

\footnotetext{
107 Ibídem: fol. 19

108 Ibídem: fol. 18

109 Ibídem: fol. 23.
} 
aprobó y luego en Murcia, a 11 de marzo de 1810, hizo lo propio el obispo. ${ }^{110}$

La constitución de la asociación, así como la composición de su junta directiva, muestran de manera evidente la existencia de unos lazos que unían a los oficiales de la Armada $-y$ a sus mujeres- con miembros del clero, sobre todo regular. El caso más paradigmático es el del capitán general con el prior de Santo Domingo, asiduo visitante de su casa, ya fuera solo, ya en compañía de otros eclesiásticos. ${ }^{111}$ Es más que probable que esta sintonía de intereses estuviera detrás de la instalación en 1813 de la parroquia castrense en la iglesia de Santo Domingo.

En cualquier caso la alianza entre religiosos y militares continuará años después. En enero de 1813 se nombra como médico de la asociación a Diego Conejo, " $1^{\mathrm{er}}$ profesor retirado de medicina y sirugia de la Armada Nacional». ${ }^{112} \mathrm{Y}$ años después, a inicios de 1814, en la junta directiva seguían predominando los miembros de la Armada:

El Rmo. D. Fr. Diego Aguilar, Presidente de la Junta y Prior de Sn. Isidoro, convento de la Religión de Sto. Domingo.

El Rmo. D. Fr. Tomas Gaytan, Zelador del culto divino y Guardian del convento de Sn. Diego, Religiosos Franciscos Descalzos.

El sor. Dn. Pedro Ruiz Mateos, Brigadier de la Armada Nacional, Governador interino de esta ciudad, Clavario.

El sor. Dn. Francisco Millau, Capitan de Navio, Mor. Gral, de este Departamento, Tesorero de la Asociacion.

El sor. Dn. Antonio Muñoz, Capitan de Fragata, Clavario.

El sor. Dn. Joaquin Bilvao, Capitan de Fragata, Secretario.

El Ho. Geronimo Navarro, Donado profeso del convento de San Diego, primer Congregador. ${ }^{113}$

El 2 de marzo de ese año la junta directiva visitó al obispo de la diócesis, que se encontraba de paso en Cartagena alojado en casa del cura de la ciudad, Bernardino Rolandi, para que participara en una celebración religiosa auspiciada por la asociación. El prelado aceptó la invitación, lo que contribuyó a dar esplendor a la ceremonia celebrada en la iglesia del convento de San Diego, el 10 de marzo de 1814. En ella, además de participar activamente la casi totalidad del clero local, tanto regular como secular, tal y como relata el propio fraile, "asistió a la función, mucha parte de lo principal del pueblo». ${ }^{114}$ Lo más destacable en esta función religiosa es el protagonismo de la Armada: «se pusieron ocho granaderos de la Marina Nacional de guardia en la puerta de la Yglesia, a las ordenes del Prelado de este convento y Junta de Asociacion, se puso una centinela en la puerta del coro y otra en las ramas, por el mucho concurso del pueblo». ${ }^{115}$

Conviene no olvidar que hubo una parte importante de los mandos militares que defendieron la unión con la Iglesia, el mantenimiento del orden establecido, que no es otro que el sistema estamental, porque pensaban que la difusión de las nuevas ideas podían subvertir el orden social y político vigente, y que la religión servía para dar cohesión a la sociedad, por lo que debía seguir ocupando un lugar

\footnotetext{
110 Ibídem: fols. 25-26.

111 Ibídem: fol. 11.

112 Ibídem: fol. 41

113 Ibídem: fol. 44.

114 Ibídem: fol. 47

115 Ídem.
}

preeminente y había que actuar para que siguiera siendo así. A fin de cuentas, los jefes militares de la Armada habían prestado «juramento de fidelidad á la religión, al Rei y á la patria» en Cartagena el 10 de octubre de $1808 .{ }^{116}$ Por esta razón, no puede extrañar que el 30 de abril de 1812, un grupo de oficiales -entre los que se encontraban los que fueran capitanes generales de Cartagena, Baltasar Hidalgo de Cisneros y Joaquín de Cañaveral- solicitara a las Cortes de Cádiz el mantenimiento de la Inquisición:

por la urgencia del día, en que se ha quitado la máscara la impiedad y la irreligión; no podemos menos de recordar a V. M. con la debida sumisión, y con el mas reiterado empeño, que el primer decreto que expidió e intimó en Madrid el tirano Bonaparte, fue el de la extinción de esta respetable corporación, para abrir la puerta a sus máximas perniciosa y tiránicas, protectoras de la irreligión, y destructoras de la doctrina evangélica, a fin de encadenar en duros hierros a la generosa nación española en lo moral y político. Decreto infame y detestable, que no debió existir un momento, ni aún en sombra, a presencia de V. M. por ser ofensivo a las disposiciones más sagradas de la santa iglesia, y al decoro de la nación española, que siempre se ha distinguido por su religiosidad y obediencia al vicario de Jesucristo, y demás autoridades eclesiásticas. ${ }^{117}$

Lo que se trataba era de defender el orden establecido. Estos planteamientos coincidirían con los que tenían los eclesiásticos más reaccionarios y que terminarán oponiéndose a los planteamientos de las Cortes de Cádiz, puesto que suponían el fin del Antiguo Régimen. ${ }^{118}$

Finalizada la contienda, la Asociación continuó sus actividades. Sin embargo, a mediados de 1816 surgieron ciertas controversias relacionadas con la administración económica. Este episodio dio lugar a quejas contra la Junta directiva, llegándose a publicar diferentes pasquines difamatorios. Una vez más fue el hermano Jerónimo Navarro el que se ocupó de reconducir la situación y dar un nuevo impulso a la congregación, logrando la inscripción de nuevos miembros y la continuación de las prácticas piadosas en los años siguientes. ${ }^{119}$

\section{ALgUNAS CONCLUSIONES.}

La creación en Cartagena entre 1809 y 1810 de una nueva asociación religiosa en un momento de gran complejidad social, política y económica, como fue la Guerra de la Independencia, puede servir para calibrar la vivencia de la religiosidad a nivel local. La asociación respondía, en cierta medida, a los presupuestos religiosos de los ilustrados que abogaban por una vivencia rigurosa de la fe, una religiosidad que, como señala Emilio La Parra, concuerda con el ideal moral burgués de la honradez, entendida como valor superior de la piedad y como resultado de una vida interior

116 Gaceta de Madrid, no 135, 19 de octubre de 1808, p. 1310.

117 Representación que los generales y oficiales del exército contenidos en ella han hecho y presentado al augusto congreso de Cortes manifestando la urgente necesidad de que continúe en el exercicio de sus funciones el supremo tribunal de la inquisición, 30 de abril de 1812, incluido en Vélez 1812: 240-241.

118 Martínez Esteban 2009: 66.

119 AMCt. FECN. Libro de la Asociación de Jesús Sacramentado: fol. 109. 
convencida, sin que esto implique el abandono del sentido trascendente propio del catolicismo. ${ }^{120}$ Pero, por otro lado, representa una cierta tradición que enlaza con unos de los presupuestos tridentinos y que se generalizó durante el Barroco, como es el culto a la Eucaristía, el principal dogma católico. Ese contacto con el pasado se aprecia cuando se comprueba que la nueva asociación toma el testigo de la archicofradía. ¿Dónde está la novedad? Pues en el hecho de que se trata de una asociación cerrada, con un número muy limitado de miembros, los cuales, por otro lado, pertenecen a la oligarquía política y, sobre todo, militar. El peso de la Armada en la asociación es más que evidente, tanto que se puede decir que sin la intervención de sus oficiales la asociación no se hubiera creado.

La repetición constante en el libro de la asociación de crearla "sin gravar al pueblo» sirve para justificar la actuación, e incluso la existencia, de los grupos dominantes, pues a pesar de que eran malos tiempos para crear este tipo de asociaciones, se ofrecían para facilitar una ayuda espiritual a la ciudad, así como un servicio a la Monarquía, subrayando el "sacrificio" económico que les suponía cumplir con su función social. Por esto, la búsqueda de la constante aprobación, tanto del obispado como de la Junta de Observación y Defensa, revela que la asociación no sólo no quería ningún tipo de ruptura con el orden establecido, sino que pretendía apuntalarlo. Evidencia la intención de unos laicos poderosos que asumen la atención religiosa de la población; es expresión del concepto más tradicional de caridad que refuerza el paternalismo social de las elites dirigentes. Esto, por ejemplo, se comprueba cuando se relacionan las características que debían reunir las personas que debían componer su junta directiva. Del presidente, se dice que «deverá ser un sacerdote de ciencia, cordura, y providad, y de autoridad posible». El celador "será un eclesiástico de conocido afecto al culto, de conducta ejemplar». "El Tesorero que ha de ser persona de Autoridad y respeto». "El Congregador que será muy solicito por el culto del Señor». El secretario «deverá ser de acreditado celo y expediente» y «havrá dos Clavarios, cuyos oficios recaerán en personas de calidad y de reconocido afecto a las Asociación». ${ }^{121}$

La asociación cumplía un doble objetivo, quizás para dos tipos de fieles. En primera instancia, la exposición permanente del Santísimo se destinaba a una minoría que vivía una religiosidad más interior, al hilo de las pretensiones ilustradas y que, aunque no de forma exclusiva, estaría formada por componentes de las élites. Por el contrario, el segundo objetivo, el acompañamiento del viático, entroncaba con la tradicional visión de la magnificencia del culto exterior. El intento de popularizar y dignificar y, sobre todo, de hacer llegar desde un punto material a los más desfavorecidos el sacramento eucarístico, habría de entenderse como pura pedagogía oligárquica, rasgo que ya estaba presente en las cofradías nobiliarias como la cartagenera del Cristo del Socorro: los de arriba como ejemplo de los de abajo, como dice Francisco Henares. ${ }^{122}$ Al promover los grupos de notables locales la asociación, ciacaso era una respuesta ante la

120 La Parra López 1985: 13.

121 AMCt. FECN. Libro de la Asociación de Jesús Sacramentado: folio sin número.

122 Henares Díaz 1999: 58. toma de conciencia de un abandono paulatino de las prácticas religiosas?

Esta convicción sí que estaba presente entre el clero regular, ya desde la segunda mitad del siglo XVIII; por eso, tuvo un papel tan destacado en la creación de la asociación de Jesús Sacramentado. El protagonismo de los frailes en la Guerra de la Independencia ha sido repetido hasta la saciedad, incluso empuñando las armas. ${ }^{123}$ En el caso concreto de Cartagena, las comunidades religiosas fueron movilizadas para formar parte activa de la organización y defensa de la ciudad. Al margen de sus tradicionales tareas puramente religiosas o asistenciales, sus integrantes fueron requeridos para hacer cartuchos en el parque de Artillería pero, sobre todo, para vigilar las puertas de entrada a la ciudad. Así, a comienzos de 1809, los Agustinos se hicieron cargo, en un primer momento, de la puerta del Muelle, pasando posteriormente a hacer las guardias en la puerta de Madrid, en donde recogían los pasaportes de los que entraban a la ciudad, enviándose con un soldado de guardia a casa del Gobernador.

Igualmente, como ya se ha indicado, se ha insistido en el papel de los frailes como sostenedores ideológicos a través de los sermones. Pero en Cartagena, al margen de esta actividad, un fraile franciscano emprende la creación de una nueva asociación, que va a proporcionar un inmejorable testimonio de servicio a Dios, a la ciudad, a la Nación y al rey legítimo.

Alabemos a Dios Padre Omnipresente porque nos engendró, a Dios Espiritu Santo porque nos santificó y a Dios Hijo porque nos redimió y se quedó con nosotros en el augusto sacramento del Altar para nuestra felicidad y se manifestó de un modo maravilloso en los templos de esta Ciudad de Cartagena en el tiempo de la mayor aflicción por la injusta guerra que hacía a nuestro católico Reyno de España el iniquo Napoleon Emperador 1ㅇde los franceses, llamando por este medio nuestro amorosisimo Jesus a todo este Pueblo... ${ }^{124}$

Si Napoleón decreta en 1809 la disolución de las órdenes religiosas, éstas se consagran a servir la causa fernandina y se empeñan en mostrar su utilidad a la sociedad, puesto que se ocupan de algo fundamental: lograr el favor divino. El hermano Jerónimo piensa que la promoción de la asociación puede ser una buena forma de lograrlo, de tal manera que vinculará el éxito de aquélla con la victoria final: «Ea católicos el establecimiento de la Asociación es prodigioso, los franceses no han venido a Cartagena, el Rey ha venido a su trono, los Pobres han sido consolados en las epidemias». ${ }^{125}$

El fraile, tal y como era la práctica habitual de otros predicadores, explicaba que el origen de todas las calamidades residía en la falta de moralidad y en los pecados de los fieles. Por esta razón, para mantener el apoyo divino, había que rezar y, sobre todo, reconocer los pecados: «Cartagena, Cartagena, quantas gracias tienes que dar a Dios, quanta penitencia tienes que hacer». ${ }^{126}$ "Vosotros fieles asociados no agais aprecio del mundo y su luxo, y menos de aquellos que desprecian estas cosas». ${ }^{127}$

\footnotetext{
123 Pascual 2000.

124 AMCt. FECN. Libro de la Asociación de Jesús Sacramentado: fol. 1.

125 Ibídem: fol. 43.

126 Ídem.

127 Ídem.
} 
Pero el hecho más importante es que la asociación permitió recuperar el favor divino de la ciudad. Así lo cree el hermano Jerónimo, quien relata que Dolores Rosique, esposa del Francisco Millau, tesorero de la asociación, había enfermado gravemente y se esperaba su muerte en cualquier instante. Él reunió a la junta y dijo que si se le permitía instalar altares móviles para el culto del Santísimo Sacramento, la mujer curaría. Se le autorizó y la mujer se curó. Fue fácil relacionar uno y otro hecho y atribuirle la categoría de milagro y, en especial, la utilidad de la asociación: «Para mayor honra y gloria de Dios y para que los católicos sepan que todas las cosas correspondientes a la Asociacion deven atribuirse al Todopoderoso y no a una devoción particular de los hombres». ${ }^{128}$

La asociación era la cristalización de una simbiosis perfecta entre lo político y lo religioso en un ambiente bélico. Los eclesiásticos buscaban a los poderosos y éstos buscaban a la Iglesia. La asociación refleja la alianza de los grupos dominantes con la Iglesia en la más pura tradición del Antiguo Régimen, la alianza Altar-Trono a nivel local. El clero, sobre todo el regular, como encarnación de la Iglesia y la Junta de Observación y Defensa -compuesta mayoritariamente por militares- como representación de la Monarquía. Si Gregorio Alonso, al analizar los mensajes de los frailes durante la Guerra de la Convención, habla de "ascetismo militarizado", ${ }^{129}$ un tono que continuará durante gran parte del siglo XIX entre los clericales, la asociación de Jesús Sacramentado podría entenderse como una forma de "piedad militarizada". La Armada y la Iglesia dirigían las prácticas religiosas de los notables de Cartagena, alejadas de las formas de religiosidad popular, sometidas a la más pura ortodoxia, centradas únicamente en el culto divino:

Penetrado su vecindario de sentimientos tan religiosos y nobles y uniendose a iguales deseos de los respetables Cuerpos de Marina, Exercito y Politico de este Departamento, recurren a V. S. I. presentándole la justa solicitud de que se les conceda que en todos los días de obligación de Misa, se ponga de manifiesto el Señor Sacramentado en todas las Yglesias, de esta ciudad por turno, dese las hora de las 8 de la mañana en la actual estación, y la de la 7 en el verano hasta ponerse el sol, para cuya católica idea se hallan prontos y conformes la Parroquial y Comunidades deseosas de unir sus auxilios sin el menor interés para el vecindario y demás cuerpos, los proporcionará para el decoroso reverente culto. ${ }^{130}$

Los eclesiásticos beneficiaban a la ciudad como mejor sabían: velando por la salud espiritual del pueblo e intentando agradar a Dios. Por esta razón, en la primera actuación pública de la asociación, que fue la exposición del Santísimo en la iglesia de Santa María de Gracia, se implica de forma importante todo el clero de la ciudad, ya que todos los gastos fueron costeados por el cura de la parroquial y el sermón fue predicado por el lector en teología del convento del Carmen. ${ }^{131}$

Otro aspecto digno de ser tenido en consideración es el papel que desempeñaron las mujeres en todo este proceso. Como viene demostrando la historiografía reciente,

\footnotetext{
128 Ibídem: fol. 42

129 Alonso 2014: 29.

130 Ibídem: fol. 18.

131 Ibídem: fol. 17.
}

en especial desde la perspectiva de historia del género, las mujeres desempeñaron un notable papel en la Guerra de la Independencia: ${ }^{132}$ desde la participación directa en acciones bélicas, de guerrillas o de espionaje, ${ }^{133}$ hasta diferentes labores en la retaguardia para sostener la causa nacional, ya sea mediante la exaltación patriótica, ${ }^{134}$ ya fomentando el asociacionismo. ${ }^{135}$ Es en este contexto donde se inscribe la actuación de las mujeres cartageneras en la Asociación de Jesús Sacramentado, aprovechando su ventajosa posición social. Son ellas las que brindan la posibilidad al fraile para la constitución de la asociación y quiénes le abren el camino para llegar a la máxima autoridad militar, algo que no podía lograrse sin la mediación de la esposa del alto mando. Porque, sin lugar a dudas, al margen del hermano Jerónimo, la principal impulsora del establecimiento de la asociación va a ser la "capitana generala". Ya esa sola denominación desvela la posición que dicha mujer gozaba entre las élites locales; aunque algo chocante es que el fraile nunca mencione su nombre, a pesar del protagonismo que tuvo en el éxito de la asociación. ${ }^{136}$ Igualmente hay que destacar que la primera asociada fuera una mujer y que no fuera la única. Sin embargo, toda la cúpula directiva estaba integrada por hombres. En efecto, como se desprende de su constitución, se establece que se forme

una Junta de solas siete personas que de importancia y estabilidad y promueva esta devocion adoptando los medios mas prudentes para su economia como para su gobernación: en ella debe haver Presidente, Zelador, Tesorero, Congregador, Secretario y dos Clavarios. ${ }^{137}$

Al final, los cargos de la junta de la asociación de Jesús Sacramentado se los repartieron entre los eclesiásticos (sobre todo, regulares) y los oficiales de la Armada. Una vez concluida la Guerra de la Independencia y con el retorno de Fernando VII, tanto unos como otros pudieron presentarse como los principales sostenedores de la ciudad, tanto desde el punto de vista material como espiritual. Habían ejercido de líderes, cumpliendo con la misión que se esperaba de cada una de ellas: la defensa militar y la atención religiosa. Los oficiales de la Armada y los eclesiásticos podían reivindicar su utilidad social y, en consecuencia, su posición privilegiada y su facultad para intervenir en los asuntos locales. En este convencimiento habrían de seguir varios años.

\section{BiBLIOGRAFÍA}

Alonso, G. 2014. La Nación en capilla. Ciudadanía católica y cuestión religiosa en España (1793-1874). Granada: Comares.

Andrés-Gallego, J. 2009. "Iglesia y Guerra en 1808: el estado de la cuestión». Ciudad de Dios: Revista agustiniana 222: 749-781.

Andrés-Gallego, J., y Pazos, A. 1999. La Iglesia en la España contemporánea, 1: 1800-1936. Madrid: Encuentro.

\footnotetext{
132 Castells, Espigado y Romeo (coords.) 2009.

133 Reder Gadow 2011.

134 Espigado 2009: 709-749.

135 Fernández García 2009.

136 Se trataba de Margarita Pascual de Pobil y García Menocal, natural de La Habana, hija de Miguel Pascual del Pobil y Canicia, Capitán de Navío de la Real Armada, y de María de la Concepción García Menocal (De la Válgoma y Díaz Varela 1954: 324).

137 AMCt. FECN. Libro de la Asociación de Jesús Sacramentado: folio
} sin número. 
Arias de Saavedra, I. y López-Guadalupe Muñoz, M. L. 2002. La represión de la religiosidad popular. Crítica y acción contra las cofradías en la España del siglo XVIII. Granada: Universidad de Granada.

Artola Renedo, A. 2013. De Madrid a Roma. La fidelidad del episcopado en España (1760-1833). Gijón: Ediciones Trea.

Artola Renedo, A. 2014. El control del espacio eclesiástico durante el reinado de José I. [Documento de trabajo], disponible en: https:// hal.archives-ouvertes.fr/hal-00989154v1

Barbastro Gil, L. 1987. Revolución liberal y reacción, 1808-1833. Protagonismo ideológico del clero en la sociedad valenciana. Alicante: Caja de Ahorros Provincial de Alicante.

Barbastro Gil, L. 2013. El episcopado español y el alto clero en la Guerra de la Independencia (1808-1814). Alicante: Instituto Alicantino de Cultura Juan Gil Albert.

Barnosell Jordá, G. 2010. «La Guerra de la Independencia como guerra religiosa: el ejemplo de los sitios de Zaragoza y Gerona». Nuevo mundo, mundos nuevos 10, disponible en: http://nuevomundo. revues.org/59671

Barrio Gozalo, M. 2007, "Actitudes del clero secular ante el gobierno de José I durante la Guerra de la Independencia». Cuadernos dieciochistas 8: 159-185, disponible en: http://campus.usal.es/ revistas_ trabajo/index.php/1576-7914/article/view/772/7060.

Barrio Gozalo, M. 2012. «El discurso político-religioso del clero español en el contexto de la Guerra de la Independencia (1808-1813)». Anales valentinos: revista de filosofía y teología 75: 9-42.

Calvo Maturana, A. J. 2011. "Aquel manda las conciencias..." Iglesia y adoctrinamiento político en la Monarquía Hispánica (1780-1808). Cádiz: Ayuntamiento de Cádiz.

Candel Crespo, F. 1981. La devoción al Sagrado Corazón de Jesús en Murcia. Murcia: Edición del autor.

Candel Crespo, F. 2003. La Murcia eclesiástica durante la Guerra de la Independencia (1808-1814). Murcia: Edición del autor.

Carralero Alarcón, J. L. y Espín García, J. 2009. Treinta y tres corazones. Historia de la llustre Cofradía del Santísimo y Real Cristo de Socorro. Cartagena: Ilustre Cofradía del Santísimo y Real Cristo del Socorro.

Castells, I., Espigado, G. y Romeo, M. C. (coords.). 2009. Heroínas y patriotas. Mujeres de 1808. Madrid: Cátedra.

Castells, J. M. 1973. Las asociaciones religiosas en la España contemporánea. Un estudio jurídico-administrativo (1767-1965). Madrid: Taurus.

Cortés Peña, A. L., y López-Guadalupe, M. L. 2010. «Historiografía sobre la Iglesia en Andalucía (Edad Moderna)». Tiempos Modernos 20, disponible en: http://www.tiemposmodernos.org/tm3/index. php/tm/article/viewFile/213/268

De la Cueva Merino, J. 1994. Clericalismo y anticlericalismo en Cantabria. Santander: Universidad de Cantabria.

De la Válgoma y Díaz Varela, D. 1954. Real Compañía de Guardias Marinas y Colegio Naval: catálogo de pruebas de caballeros aspirantes, V. Madrid: Instituto Histórico de Marina.

Domínguez Ortiz, A. 1976. Sociedad y estado en el siglo XVIII español. Barcelona: Ariel.

Egea Bruno, P. M. 1991. «El siglo XIX. Hacia la institucionalización», en C. Ferrándiz Araujo y A. J. García Bravo (coords.). Las cofra días pasionarias de Cartagena: 241-369. Cartagena: Asamblea Regional de Murcia.

Egido, T. 1979. «El regalismo y las relaciones Iglesia-Estado en el siglo XVIII», en R. García Villoslada (dir.), Historia de la Iglesia en España IV: La Iglesia en la España de los siglos XVII y XVIII: 122-249. Madrid: Biblioteca de Autores Cristianos.

Espigado, G. 2009. «Armas de mujer: el patriotismo de las españolas en la Guerra de la Independencia» en E. de Diego García, J. L. Martínez Sanz (coords.). El comienzo de la Guerra de la Independencia: 709749. Madrid: Actas.

Faria, A. Mouta 2014. «Referentes religiosos en los discursos políticos del primer liberalismo portugués», en R. Serrano García, A de Prado Moura y E. Larriba (eds.). Discursos y devociones religiosas en la Península Ibérica, 1780-1860. De la crisis del Antiguo Régimen a la consolidación del Liberalismo: 141-150. Valladolid: Universidad de Valladolid.
Fernández Araujo, C. 1999. «Nuevas aportaciones al conocimiento de la tricentenaria cofradía del Socorro de Cartagena», en Cofradía del Cristo del Socorro. Trescientos años (1691-1991): 31-45. Cartagena: Cajamurcia.

Fernández García, E. 2009. Mujeres en la guerra de la independencia. Madrid: Sílex.

Fraser, R. 2006. La maldita Guerra de España. Historia social de la Guerra de la Independencia 1808-1814. Barcelona: Crítica.

Gómez Vizcaíno, J. A. 2007. "La defensa de la plaza de Cartagena durante la Guerra de la Independencia (1808-1814)», en Cartagena y su Departamento Marítimo en la Guerra de la Independencia: 29-54. Cartagena: Instituto de Estudio Carthaginenses.

Henares Díaz, F. 1999. "Honor y lustre en la cofradía cartagenera del Cristo del Socorro (1691)», en Cofradía del Cristo del Socorro. Trescientos años (1691-1991): 47-66. Cartagena: Cajamurcia.

Herradón Figueroa, M. A. 2009. "Reinaré en España. La devoción al Sagrado Corazón de Jesús". Revista de Dialectología y Tradiciones Populares 64: 193-218.

Herrero, J. 1988. Los orígenes del pensamiento reaccionario español. Madrid: Alianza.

Irigoyen López, A., y García Hourcade, J. J. 2001. Visitas ad limina de la diócesis de Cartagena, 1593-1901. Murcia: Universidad Católica de Murcia.

Jiménez Duque, B. 1979. "Espiritualidad y apostolado», en R. García Villoslada (dir.), Historia de la Iglesia en España, V: La Iglesia en la España contemporánea: 395-474. Madrid: Biblioteca de Autores Cristianos.

La Parra López, E. 1985. El primer liberalismo español y la Iglesia. Alicante: Instituto de Estudios Juan Gil-Albert.

López, F. 1987-1988. "La resistencia a la Ilustración: bases sociales y medios de acción", en M. Batllori (coord.), La época de la Ilustración, el Estado y la cultura (1759-1808): 767-812. Historia de España fundada por Ramón Menéndez Pidal, XXXI/1. Madrid: Espasa Calpe.

Maestre de San Juan, F. y Montojo Montojo, V. 1999. La Cofradía de Nuestro Padre Jesús Nazareno (Marrajos) durante la edad moderna. Cartagena: Ilustre Cofradía de Nuestro Padre Jesús Nazareno.

Marín Cano, A. 2008. Muerte, beneficencia, religiosidad y cofradías. La Cofradía de Ánimas de Cieza (1574-1997). Cieza: Cofradía de Ánimas de Cieza.

Martínez Albiach, A. 1969. Religiosidad hispana y sociedad borbónica. Burgos: Publicaciones de la Facultad de Teología del Norte de España.

Martínez Esteban, A. 2009. "llustrados, regalistas y reformistas», en J. M. Magaz Fernández (ed.). La Iglesia en los orígenes de la España contemporánea (1808): 13-70. Madrid: Publicaciones de la Facultad de Teología San Dámaso.

Martínez Rizo, I. 1894. Fechas y fechos de Cartagena. Cartagena: Imprenta Hipólito García e Hijos.

Martínez Ruiz, E., y Gil, M. 2010. La Iglesia española contra Napoleón. La guerra ideológica. Madrid: Actas.

Maruri, R. 2014. «Los santos de la comunidad: devociones religiosas en la Cantabria occidental (siglos XVIII-XIX)», en R. Serrano García, A. de Prado Moura y E. Larriba (eds.). Discursos y devociones religiosas en la Península Ibérica, 1780-1860. De la crisis del Antiguo Régimen a la consolidación del Liberalismo: 163-196. Valladolid: Universidad de Valladolid.

Montojo Montojo, V. 1993. "Las cofradías pasionarias de Murcia en la Edad Moderna: aproximación histórica», en Real y Muy llustre Cofradía de Nuestro Padre Jesús Nazareno, disponible en: http:// www.cofradiadejesus.com/docdow.php?id=11

Montojo Montojo, V. 2011. «Francisco Salzillo, la Cofradía de Jesús y el Paso de la Cena», en V. Montojo Montojo, (coord.). Murcia, Francisco Salzillo y la Cofradía de Jesús: 269-283. Murcia: Real y Muy llustre Cofradía de Nuestro Padre Jesús Nazareno.

Montojo Montojo, V., y Cobarro Jaén, J. col. 1991. «Organización social y actividades religiosas, festivas y asistenciales: los siglos XVI y XVII», en C. Ferrándiz Araujo y A. García Bravo (coords.). Las cofradías pasionarias de Cartagena: 33-130. Cartagena: Asamblea Regional de Murcia. 
Moreno Alonso, M. 2014. El clero afrancesado en España. Los obispos, curas y frailes de José Bonaparte. Madrid: Biblioteca Nueva.

Nadal, J. 1984. Historia de la población española, siglos XVI-XX. Barcelona: Ariel.

Pascual, P. 2000. Curas y frailes guerrilleros en la Guerra de la Independencia. Zaragoza: Institución Fernando el Católico.

Piñar López, J. J. 1986. "Cartagena en los inicios de la Guerra de la Independencia. 1808», en I Concurso de Historia de Cartagena Federico Casal: 207-332. Cartagena: Ayuntamiento de Cartagena.

Pulido Serrano, J. I. 2004. «La Hermandad y Hospital de San Antonio de los portugueses de Madrid». Anales del Instituto de Estudios Madrileños 44: 299-330.

Reder Gadow, M. 2011. «Mujeres en las Barricadas durante la Guerra de la Independencia (1808-1814): la rondeña María García "La Tinajera"». Dossiers feministes 15: 9-25.

Revuelta González, M. 1979. "La Iglesia española ante la crisis de Antiguo Régimen», en R. García Villoslada (dir.), Historia de la Iglesia en España, V: La Iglesia en la España contemporánea: 3-114. Madrid: Biblioteca de Autores Cristianos.

Revuelta González, M. 2009. «El sentido religioso de la Guerra de la Independencia», en J. M. Magaz Fernández (ed.). La Iglesia en los orígenes de la España contemporánea (1808): 207-281. Madrid: Publicaciones de la Facultad de Teología San Dámaso.

Robles Muñoz, C. 1987. "La diócesis de Cartagena durante la Restauración (1875-1900)». Murgetana 78: 69-105.

Robles Muñoz, C. 2010. "Reformas y religión en las Cortes de Cádiz (1810-1813)». Anuario de Historia de la Iglesia 19: 95-117.

Roda Alcantud, C. 2007. «El Departamento Marítimo de Levante en torno a la Guerra de la Independencia», en Cartagena y su Departamento Marítimo en la Guerra de la Independencia: 55-67. Cartagena: Instituto de Estudio Cartaginenses.

Roda Alcantud, C. 2008. "La guerra de la Independencia en Cartagena y su Departamento Marítimo», en E. de Diego García (dir.) y J. L. Martínez Sanz (coord.), El comienzo de la Guerra de la Independencia. Congreso Internacional del Bicentenario de la Guerra de la Independencia Española, Madrid, 8-11 abril 2008. Madrid: Universidad Complutense. CD-ROM.

Roda Alcantud, C. 2011. «El final del Antiguo Régimen y la primeras décadas de la España Liberal en los arsenales de la península», en
Estudios de Historia Naval. Actitudes y medios en la Real Armada del siglo XVIII: 91-124. Murcia: Editum-Ministerio de Defensa.

Roda Alcantud, C. 2014. "La Base Naval de Levante y la industria naval en el contexto político, económico y social de la Región de Murcia», en E. Nicolás Marín (ed.). Historia Contemporánea de la Región de Murcia: 70-105. Murcia: Editum.

Sánchez Baena, J. J. 2012. «Aspirantes a oficiales de la Real Armada en la Academia ilustrada del Mediterráneo: esplendor y crisis (17761824)», en M. R. García Hurtado (ed.), La Armada española en el siglo XVIII. Ciencia, hombres y barcos: 329-361. Madrid: Sílex.

Sánchez Baena, J. J. y Bouzón Calvo, L. 2010. «La Armada y los acontecimientos de 1808: crisis y conflictos en el Departamento Naval de Cartagena», en C. Navarro Azcue, A. Amadori y M. Luque Talván (eds.). Una crisis atlántica: España, América y los acontecimientos de 1808: 335-355. Madrid: Universidad Complutense de Madrid.

Soler, L. 1777. Cartagena de España Ilustrada; su antigua silla metropolitana vindicada; su hijo S. Fulgencio, doctor, y su prelado, defendido. Primera parte. Murcia: ed. por Francisco Benedito.

Soler Cantó, J. 1988. "Parroquia castrense de Cartagena». Revista de Historia Naval 20: 61-76.

Suárez Cortina, M. 2014: Entre cirios y garrotes. Política y religión en la España contemporánea, 1808-1936. Santander: Universidad de Cantabria.

Torres Sánchez, R. 1990. Aproximación a las crisis demográficas en la periferia peninsular. Las crisis de Cartagena durante la Edad Moderna. Cartagena: Ayuntamiento de Cartagena.

Vélez, R. 1812. Preservativo contra la irreligión. Madrid: Imprenta de Ibarra.

Vilar, J. B., y Vilar García, M. J. 2012. Mujeres, Iglesia y secularización. El monasterio de Santa Clara la Real de Murcia en el tránsito de la Ilustración al Liberalismo (1788-1874). Murcia: Editum. Ediciones de la Universidad de Murcia.

Vilar García, M. J. 2008. «Devociones, hermandades y cofradías como instrumentos de proyección social de los institutos religiosos. El caso del monasterio de Santa Clara la Real en Murcia (siglo XIX)", en El culto a los santos: cofradías, devoción, fiestas y arte: 815-828. San Lorenzo de El Escorial: Instituto Escurialense de Investigaciones Históricas y Artísticas. 